\title{
BACILLUS ENTERITIDIS INFECTION IN LABORATORY RATS
}

\author{
PAUL R. CAN N ON \\ From the Department of Hygiene and Bacteriology, University of Chicago
}

Spontaneous infections among laboratory rodents, associated with organisms of the paratyphoid-enteritidis group, are not uncommon. Such epidemics have been described by many observers. ${ }^{1}$ Unfortunately, there is much confusion in regard to the identification of the organisms concerned in many of the epidemics, as exact cultural and serologic tests were not always used. Consequently, it is not certain whether the bacilli isolated from these epidemics were strains of B. enteritidis, suipestifer or true paratyphoid bacilli.

An epidemic associated with organisms of this group recently developed in this laboratory in a stock of white rats, 6 days after the animals had been received. During a period of 4 weeks, 45 rats of 52 died. Previous to the outbreak there had been no deaths among the 24 rats then in stock. The rats were obtained from various places in the city and were apparently in healthy condition when received.

The rats, when infected, became listless and showed no inclination for food. Shortly before death, they were unable to sustain their own weight and were found in a sprawling position. In practically every case, there were evidences of diarrhea, and in some cases the rectum was bloody. The eyes also were affected, bloody crusts usually forming around them just before death.

The spleen was usually enlarged, in some cases being almost twice its normal size. The surface of the liver was, in many instances, dotted with small, milky areas, evidently small foci of necrosis. Frequently the small intestines were filled with bloody material and Peyer's patches were prominent.

\section{ORGANISMS ISOLATED}

A paratyphoid-like organism was isolated from the heart blood of 31 rats of 35 examined. B. proteus was obtained in 2 cases, and B. coli in 2 . The predominant organism was a gram-negative, motile bacillus

Received for publication Jan. 17, 1920.

1 Loeffer: Centralbl. f. Bakteriol., 1892, 11, p. 129; Danysz: Ann. de l'Inst. Pasteur, 1900, 14, P. 193; Issatschenko: Centralbl, f. Balkteriol., 1898, 23, p. 873; Trautmann: Ztechr. f. Hyg. u. Infectionskr., 1906, 54, p. 104; Savage: J. Hygiene, 1912, 12, p. 1; Bainbridge: J. Path. \& Bacteriol., 1909, 13, p. 443; Petrie and O'Brien: J. Hygiene, 1910, 10, p. 287; Pappenheimer and Von Wedel: J. Infect. Dis., 1914, 14, p. 180. 
which fermented the following carbohydrates, with the formation of gas: glucose, maltose, levulose, mannite, galactose and dulcite, but had no effect on lactose, saccharose, dextrin, inulin and salicin. In lead acetate agar, there was a browning of the medium at the end of 24 hours. In litmus milk the reaction, at the end of 24 hours, was slightly acid, but after 3 or 4 days it became markedly alkaline. Gelatin was not liquefied in 30 days. No indol was produced in trypsinized casein medium by any of these organisms.

\section{AGGLUTINATIONS}

As shown by the table, the organism (R. 1) is B. enteritidis serologically, since it is agglutinated by $B$. enteritidis serum to the full titer of the serum, absorbs B. enteritidis agglutinin, is not agglu tinated by B. paratyphosus B or suipestifer serum, and does not absorb B. paratyphosus $B$ or suipestifer agglutinins from their respective serums. Furthermore, the immune serum from this organism agglutinates $B$. enteritidis to the full titer of the serum, but does not agglutinate B. suipestifer or B. paratyphosus A or B.

TABLE 1

Agglutination Tests

\begin{tabular}{|c|c|c|c|c|c|c|c|}
\hline Organfsms & $\begin{array}{l}\text { B. Enter- } \\
\text { itidis 52 } \\
\text { Serum }\end{array}$ & $\begin{array}{l}\text { B. Enter- } \\
\text { itídis 52 } \\
\text { Serum } \\
\text { after } \\
\text { Ab- } \\
\text { sorption } \\
\text { with } \\
\text { R. 1 }\end{array}$ & $\begin{array}{c}\text { B. Para- } \\
\text { typhosus } \\
\text { B } 12 \\
\text { Serum }\end{array}$ & $\begin{array}{c}\text { B. Sui- } \\
\text { pestifer } \\
118 \\
\text { Serum }\end{array}$ & $\begin{array}{c}\text { B. Para- } \\
\text { typhosus } \\
\text { B } 12 \\
\text { Serum } \\
\text { after } \\
\text { Ab- } \\
\text { sorption } \\
\text { with } \mathrm{R} \text {. } 1\end{array}$ & $\begin{array}{c}\text { B. Suj- } \\
\text { pestifer } \\
118 \\
\text { Serum } \\
\text { after } \\
\text { Ab- } \\
\text { gorption } \\
\text { with R. } 1\end{array}$ & $\underset{\text { Serumn }}{\text { R. } 1}$ \\
\hline $\begin{array}{l}\text { R. } 1 . \ldots \ldots \\
\text { B. suipestifer } 118 . \ldots \\
\text { B. paratyphosus B.... } \\
\text { B. enteritidis } 228 . \ldots \\
\text { B. enteritjdis } 52 . \ldots \ldots \\
\text { B. paratyphosus } \mathrm{A4} . \\
\text { B. paratyphosus } \mathrm{A} 212\end{array}$ & $\begin{array}{r}12,800 \\
0 \\
0 \\
12,800\end{array}$ & $\begin{array}{r}400 \\
0 \\
0 \\
400 \\
0\end{array}$ & $\begin{array}{r}0 \\
6,400 \\
6,400 \\
0 \\
0 \\
0\end{array}$ & $\begin{array}{r}0 \\
1,600 \\
200 \\
0 \\
0\end{array}$ & $\begin{array}{r}0 \\
3,200 \\
3,200 \\
0\end{array}$ & $\begin{array}{r}0 \\
800 \\
0\end{array}$ & $\begin{array}{r}6,400 \\
0 \\
0 \\
6,400 \\
6,400 \\
0\end{array}$ \\
\hline
\end{tabular}

The figures give the highest dilution of the serum eausing deflnite agglntination.

The tests were made with 24 -hour growths of organisms from agar glants, suspended in salt solvtion. Saturations were made by adding scrapings of 5 agar slants to a $1: 100$ dilution of serum, incubating for two hours at $37 \mathrm{C}$., centrifuging, repeating with 5 more slant: and then using the clear supernatant serum for agglutination. The known stralng of $B$. enteritidis, $B$. suipestifer and $B$. paratyphosus $A$ are from Jordan's collection.2 The $B$. paraty. phosus B (Asam) strain was isolated by the writer from a cage of paratyphoid fever and has proved by absorption tests to be a typical strain of $B$. paratyphosus $B$.

A survivor of the epidemic, rat 40 , could not be infected by feeding the organisms, and was killed. The blood of this rat did not coagulate in 15 minutes and the Peyer's patches in the ileum were very thin as though the mucosa had sloughed off, in marked contrast to those in a normal young rat.

2 Jordan: Jour. Infect. Dis., 1917, 20, p. 457. 
The serum agglutinated both R. 1 and B. enteritidis but not B. suipestifer, B. paratyphosus $A$ or $B$. This rat had, undoubtedly, had the disease and recovered. As focal necrosis of the liver is a usual condition in $B$. enteritidis infection in rats, the decreased coagulability of the blood may have been due to a decrease in fibrinogen.

\section{Pathogenicity}

A male rat, weighing $127 \mathrm{gm}$. injected intraperitoneally with $0.5 \mathrm{cc}$ of a 24-hour broth culture, died at the end of 72 hours. A $94 \mathrm{gm}$. rat, injected in a similar manner with $1 \mathrm{cc}$ died within 16 hours. A rat injected subcutaneously with $1 \mathrm{cc}$ of a 24 -hour broth culture died at the end of 5 days. A rat fed with 24-hour broth cultures died at the end of 7 days. In all cases, B. enteritidis was recovered from the heart blood and spleen.

\section{Mode of Spreading}

Flies doubtless played a part in spreading the infection, as they were very numerous. After screening the cages, the epidemic came to an end. Most of the rats were infested with fleas, and in two instances in which fleas were put into broth, B. enteritidis was recovered. However, fleas from infected rats, when placed on other rats, did not cause infection. Food, which was constantly being contaminated by the rats themselves, may also have furthered the spreading of the disease.

\section{SUMMARY}

In an epidemic among white laboratory rats, extending over a period of four weeks, 45 of 52 died. An organism which is culturally and serologically identical with $B$. enteritidis was isolated from the heart blood of 31 of 35 rats examined. This organism, when injected intraperitoneally or subcutaneously into other rats, or when fed, caused the death of the rats, and the organism was recovered from the heart blood and spleen. 